\title{
Constitutional Isomerism IV. Synthesis and Characterization of Poly(amide-ester)s from Isophthaloyl Chloride and 4-Aminophenethyl Alcohol
}

\author{
Li Li, Koichiro Yonetake, ${ }^{*}$ Osamu HabA, ${ }^{*}$ Takeshi Endo, ${ }^{*}$ and Mitsuru UedA ${ }^{* *,}{ }^{\dagger}$ \\ Department of Human Sensing and Functional Sensor Engineering, Graduate School of \\ Engineering, Yamagata University, Yonezawa, Yamagata 992-8510, Japan \\ * Department of Polymer Chemistry, Graduate School of Engineering, \\ Yamagata University, Yonezawa, Yamagata 992-8510, Japan \\ ** Department of Organic and Polymeric Materials, Tokyo Institute of Technology, \\ Meguro-ku, Tokyo 152-8552, Japan
}

(Received November 28, 2000; Accepted January 24, 2001)

\begin{abstract}
The ordered [head-to-head $(\mathrm{H}-\mathrm{H})$ or tail-to-tail $(\mathrm{T}-\mathrm{T})]$ poly(amide-ester) was prepared by direct polycondensation of a symmetric monomer, isophthaloyl chloride with 4-aminophenethyl alcohol as a nonsymmetric monomer. The polymerization was conducted in NMP in the presence of triethylamine (TEA) at $0^{\circ} \mathrm{C}$ by slow addition of isophthaloyl chloride to 4-aminophenethyl alcohol, giving the ordered $\mathrm{H}-\mathrm{H}$ or $\mathrm{T}-\mathrm{T}$ poly(amide-ester) with an inherent viscosity of $0.30 \mathrm{dL} \mathrm{g}^{-1}$, measured at a concentration of $0.5 \mathrm{~g} \mathrm{dL}^{-1}$ at $30^{\circ} \mathrm{C}$ in NMP. The authentic $\mathrm{H}-\mathrm{H}$ or $\mathrm{T}-\mathrm{T}$ and random poly(amide-ester)s were prepared respectively to varify the structure of ordered polymer. The microstructure of polymers obtained was investigated by ${ }^{1} \mathrm{H}$ and ${ }^{13} \mathrm{C}$ spectroscopy, and it was found that the polymers obtained by direct polycondensation had the expected $\mathrm{H}-\mathrm{H}$ or $\mathrm{T}-\mathrm{T}$ ordered structure. The model reactions were studied in detail to demonstrate the feasibility of polymer formation. $\mathrm{H}-\mathrm{H}$ or T-T ordered polymer was crystalline; On the other hand, the random poly(amide-ester) was amorphous. Furthermore, physical properties of $\mathrm{H}-\mathrm{H}$ or $\mathrm{T}-\mathrm{T}$ ordered polymer were compared with poly(amide-ester) obtained from isophthaloyl chloride and 4-(2-aminoethyl)phenol (constitutional isomer of monomer 4aminophenethyl alcohol).
\end{abstract}

KEY WORDS Constitutional Isomerism / Poly(amide-ester) / Isophthaloyl Chloride / 4Aminophenethyl Alcohol /

Constitutional isomerism is encountered when polymers have the same overall chemical composition but atoms or groups of atoms are connected in different orders. The different examples of constitutional isomerism are important to note from the practical viewpoint, since the isomeric polymers usually differ considerably in their properties. Structure-property relationships arising from constitutional isomerism, however, are not well known for condensation polymers. Therefore, it is very important to establish the method for the synthesis of ordered polymer from nonsymmetric monomers and to clarify the structure-property relationships between condensation polymers with different regularities.

We have been interested in developing the synthetic method for constitutional isomeric condensation polymers from nonsymmetric monomers, ${ }^{1}$ and also in clarifying a structure-property relationship between constitutional isomers., ${ }^{2,3}$ Recently, we reported the synthesis and characterization of ordered poly(amide-ester)s from isophthaloyl chloride (1) and 4-(2-aminoethyl)phenol. ${ }^{2}$ This investigation revealed that the constitutional regularity of the polymers greatly influenced the solubility, thermal property and crystallinity. The DSC traces of the first-heating process for the ordered poly(amideester)s showed clear endothermic peaks, but no such peaks were observed in the second-heating process, which means no crystalline could be formed on the cooling process. The chain mobility seemed to be restricted by hydrogen bonds between the intermolecular or intra- molecular amide bonds and rigid arylate bonds.

We selected 4-aminophenethyl alcohol (2) as a nonsymmetric monomer for studies of the influence of constitutional isomers on the physical properties of polycondensations. Monomer 2 is the constitutional isomer of 4 (2-aminoethyl)phenol, and an aliphatic ester bond was expected to induce the chain mobility and to increase the crystallization rate of poly(amide-ester).

In this paper, we report the synthesis and properties of ordered poly(amide-ester) from direct polycondensation of $\mathbf{1}$ and $\mathbf{2}$.

\section{EXPERIMENTAL}

\section{Materials}

$N$-Methyl-2-pyrrolidinone (NMP) was purified by vacuum distillation and stored over $4 \AA$ molecular sieves. Isophthaloyl chloride (1) and 4-aminophenethyl alcohol (2) were purified by recrystallization from hexane and EtOH respectively. Benzoyl chloride was purified by vacuum distillation (bp: $69^{\circ} \mathrm{C} / 6 \mathrm{mmHg}$ ). Triethylamine (TEA) and tetrahydrofuran (THF) were purified by usual methods. Other reagents and solvents were obtained commercially and used as recieved.

The excellent condensing agent diphenyl (2,3-dihydro2-thioxo-3-benzoxazolyl) phosphonate (DBOP) was prepared according to the reported procedure. ${ }^{4}$ 
Competitive Reaction of Aniline and Phenethyl Alcohol with Benzoyl Chloride

Aniline $(0.09 \mathrm{~mL}, 1.0 \mathrm{mmol})$, phenethyl alcohol $(0.12$ $\mathrm{mL}, 1.0 \mathrm{mmol})$, and TEA $(0.15 \mathrm{~mL}, 1.1 \mathrm{mmol})$ were dissolved in NMP $(1 \mathrm{~mL})$ at $0^{\circ} \mathrm{C}$. To this solution was added benzoyl chloride $(0.12 \mathrm{~mL}, 1.0 \mathrm{mmol})$ in NMP $(1 \mathrm{~mL})$. After stirring for $1 \mathrm{~h}$ in air, the product-ratio was determined by HPLC (acetanilide as internal standard). The reaction yielded a single product, benzanilide. The yield was $100 \%$, mp: $163-164^{\circ} \mathrm{C}$ (Lit. $\mathrm{mp}: 163^{\circ} \mathrm{C}^{5}$ ). IR (KBr) $1656(\mathrm{C}=\mathrm{O}), 3344 \mathrm{~cm}^{-1}(\mathrm{NH}) .{ }^{1} \mathrm{H}$ NMR (DMSO-d ${ }_{6}$, $\mathrm{ppm}): \delta 10.25(\mathrm{~s}, 1 \mathrm{H}, \mathrm{NH})$.

\section{Polymer Synthesis}

Authentic Ordered ( $H-H$ or $T-T)$ Poly(amide-ester) (3a). [4'-(2-hydroxyethyl)]isophthaldianilide (4). To a solution of $2(0.274 \mathrm{~g}, 2.0 \mathrm{mmol})$ and TEA $(0.28 \mathrm{~mL}, 2.0$ $\mathrm{mmol})$ in NMP $(4 \mathrm{~mL})$ at $0^{\circ} \mathrm{C}$ was slowly added $1(0.203$ $\mathrm{g}, 1.0 \mathrm{mmol}$ ). After stirring for $5 \mathrm{~h}$, this reaction mixture was poured into $5 \% \mathrm{NaHCO}_{3}$ aqueous solution. The precipitate was filtered off, and dried. Yield was $0.396 \mathrm{~g}$ (98 $\%)$. Recrystallization from acetic acid afforded needle crystals, mp: $162-164^{\circ} \mathrm{C}$. IR (KBr) $1049(\mathrm{OH}), 1651(\mathrm{C}=$ O), $3278 \mathrm{~cm}^{-1}(\mathrm{NH}) .{ }^{1} \mathrm{H}$ NMR (DMSO- $\left.d_{6}, \mathrm{ppm}\right): \delta 10.38$ (s, 2H, NH), $4.63(\mathrm{~s}, 2 \mathrm{H}, \mathrm{OH}), 3.60(\mathrm{t}, J=7.3 \mathrm{~Hz}, 4 \mathrm{H}$, $-\mathrm{CH}_{2}-\mathrm{OH}$ ), 2.70 (t, $\left.J=7.0 \mathrm{~Hz}, 4 \mathrm{H},-\mathrm{CH}_{2}-\mathrm{CH}_{2}-\mathrm{OH}\right) .{ }^{13} \mathrm{C}$ NMR (DMSO- $d_{6}$, ppm): $\delta 164.74(\mathrm{C}=\mathrm{O}$, amide), 61.87 $\left(-\mathrm{CH}_{2}-\mathrm{OH}\right)$. Anal. Calcd for $\mathrm{C}_{24} \mathrm{H}_{24} \mathrm{~N}_{2} \mathrm{O}_{4}: \mathrm{C}, 71.27 ; \mathrm{H}$, 5.98; N, 6.93. Found: C, 71.09; H, 6.13; N, 6.74.

Poly(amide-ester) (3a). Compound 4 (0.405 g, 1.0 mmol) and TEA $(0.31 \mathrm{~mL}, 2.2 \mathrm{mmol})$ were dissolved in NMP $(2 \mathrm{~mL})$ at $0^{\circ} \mathrm{C}$. To this solution was added $1(0.212$ $\mathrm{g}, 1.05 \mathrm{mmol}$ ) in one portion. Then it was stirred at this temperature for $6 \mathrm{~h}$. The resulting polymer was precipitated by pouring the solution into $\mathrm{MeOH}$ and dried. Yield $0.518 \mathrm{~g}(97 \%)$. The inherent viscosity of the polymer in NMP was $0.32 \mathrm{dL} \mathrm{g}^{-1}$, measured at a concentration of $0.5 \mathrm{~g} \mathrm{dL}^{-1}$ at $30^{\circ} \mathrm{C}$. IR $(\mathrm{KBr}) 1651(\mathrm{C}=\mathrm{O}$, amide), $1720\left(\mathrm{C}=\mathrm{O}\right.$, ester), $3309 \mathrm{~cm}^{-1}(\mathrm{NH}) .{ }^{13} \mathrm{C}$ NMR (DMSO$\left.d_{6}, \mathrm{ppm}\right): \delta 164.70(\mathrm{C}=\mathrm{O}$, amide), $164.58(\mathrm{C}=\mathrm{O}$, ester $)$. Anal. Calcd for $\left(\mathrm{C}_{32} \mathrm{H}_{26} \mathrm{~N}_{2} \mathrm{O}_{6} \cdot 0.8 \mathrm{H}_{2} \mathrm{O}\right)_{n}$ : C, 70.01; $\mathrm{H}$, 5.07; N, 5.10. Found: C, 69.74; H, 5.01; N, 4.81.

Poly(amide-ester) (3b). $2(0.274 \mathrm{~g}, 2.0 \mathrm{mmol})$ and TEA (0.62 mL, $4.4 \mathrm{mmol})$ was dissolved in NMP (4 mL) at $0^{\circ} \mathrm{C}$, to this solution was added $1(0.426 \mathrm{~g}, 2.1 \mathrm{mmol})$ during $20 \mathrm{~min}$. After stirring the solution at this temperature for $6 \mathrm{~h}$, the resulting polymer was isolated as described above, yield $0.521 \mathrm{~g}(98 \%)$. The inherent viscosity of polymer in NMP was $0.30 \mathrm{dL} \mathrm{g}^{-1}$, measured at a concentration of $0.5 \mathrm{~g} \mathrm{dL}^{-1}$ at $30^{\circ} \mathrm{C}$. IR $(\mathrm{KBr}) 1651(\mathrm{C}=$ $\mathrm{O}$, amide), $1720(\mathrm{C}=\mathrm{O}$, ester $), 3309 \mathrm{~cm}^{-1}(\mathrm{NH}),{ }^{13} \mathrm{C}$ NMR (DMSO- $\left.d_{6}, \mathrm{ppm}\right): \delta 164.70(\mathrm{C}=\mathrm{O}$, amide), 164.58 $(\mathrm{C}=\mathrm{O}$, ester $)$. Anal. Calcd for $\left(\mathrm{C}_{32} \mathrm{H}_{26} \mathrm{~N}_{2} \mathrm{O}_{6} \cdot 0.8 \mathrm{H}_{2} \mathrm{O}\right)_{n}$ : $\mathrm{C}$, 70.01; H, 5.07; N, 5.10. Found: C, 69.87; H, 4.84; N, 5.21.

Random Poly(amide-ester) (3c). Polymer 3c was prepared from 1 and 2 by mixing them all at once. Monomer $1(0.426 \mathrm{~g}, 2.1 \mathrm{mmol})$ was added in one portion to the solution of $2(0.274 \mathrm{~g}, 2 \mathrm{mmol})$ in NMP $(2 \mathrm{~mL})$ at room temperature with TEA $(0.70 \mathrm{~mL}, 5.0 \mathrm{mmol})$. The reaction mixture was stirred for $6 \mathrm{~h}$ and then poured into $\mathrm{MeOH}$. The polymer was obtained as described above. Yield $0.513 \mathrm{~g}(96 \%)$. The inherent viscosity of polymer in NMP was $0.28 \mathrm{dL} \mathrm{g}^{-1}$, measured at a concentration of $0.5 \mathrm{~g}$

Polym. J., Vol. 33, No. 4, 2001
$\mathrm{dL}^{-1}$ at $30^{\circ} \mathrm{C} . \mathrm{IR}(\mathrm{KBr}) 1651(\mathrm{C}=\mathrm{O}$, amide $), 1720(\mathrm{C}=\mathrm{O}$, ester), $3309 \mathrm{~cm}^{-1}(\mathrm{NH}) .{ }^{13} \mathrm{C}$ NMR (DMSO- $\left.d_{6}, \mathrm{ppm}\right): \delta$ $164.70(\mathrm{C}=\mathrm{O}$, amide), $164.58(\mathrm{C}=\mathrm{O}$, ester). Anal. Calcd for $\left(\mathrm{C}_{32} \mathrm{H}_{26} \mathrm{~N}_{2} \mathrm{O}_{6} \cdot 0.8 \mathrm{H}_{2} \mathrm{O}\right)_{n}$ : C, 70.01; H, 5.07; N, 5.10. Found: C, 69.80; H, 4.96; N, 5.13.

\section{Model Compounds}

The following model compounds were prepared from the corresponding acyl chloride with amine or alcohol.

$N, N^{\prime}$-Bis-isophthaldianilide (5). Compound $\mathbf{5}$ was prepared from aniline and $\mathbf{1}$ in the presence of TEA in THF. Yield $100 \%$. Mp: $290-291^{\circ} \mathrm{C}$ (from acetic acid). IR (KBr) $1643(\mathrm{C}=\mathrm{O}), 3255 \mathrm{~cm}^{-1}(\mathrm{NH}) .{ }^{1} \mathrm{H}$ NMR (DMSO$\left.d_{6}, \mathrm{ppm}\right): \delta 10.44(\mathrm{~s}, 1 \mathrm{H}, \mathrm{NH}) .{ }^{13} \mathrm{C}$ NMR (DMSO- $d_{6}$, ppm): $\delta 164.91(\mathrm{C}=\mathrm{O})$. Anal. Calcd for $\mathrm{C}_{20} \mathrm{H}_{16} \mathrm{~N}_{2} \mathrm{O}_{2}$ : C, 75.93; H, 5.10; N, 8.85. Found: C, 75.78; H, 5.06; N, 8.99.

$N, N^{\prime}$-Bisphenethyl Isophalate (6). Compound 6 was colorless liquid prepared from phenethyl alcohol with $\mathbf{1}$ in the presence of TEA in NMP. Yield 95\%. IR $(\mathrm{NaCl})$ $1720 \mathrm{~cm}^{-1}(\mathrm{C}=\mathrm{O}) .{ }^{1} \mathrm{H}$ NMR (DMSO- $\left.d_{6}, \mathrm{ppm}\right): \delta 4.50(\mathrm{t}$, $\left.J=7.0 \mathrm{~Hz}, 4 \mathrm{H},-\mathrm{CH}_{2}-\mathrm{O}^{-}\right), 3.03(\mathrm{t}, J=7.2 \mathrm{~Hz}, 4 \mathrm{H}, \mathrm{Ph}$ $\left.-\mathrm{CH}_{2}-\right) .{ }^{13} \mathrm{C}$ NMR (DMSO- $\left.d_{6}, \mathrm{ppm}\right): \delta 164.48(\mathrm{C}=\mathrm{O})$, $65.13\left(-\mathrm{O}^{-} \mathrm{CH}_{2}-\mathrm{CH}_{2}-\right), 33.84\left(\mathrm{Ph}-\mathrm{CH}_{2}-\right)$. Anal. Calcd for $\mathrm{C}_{24} \mathrm{H}_{22} \mathrm{O}_{4}$ : C, 76.99; H, 5.92. Found: C, 77.13; H, 6.08.

4-(Benzoylamino)phenethyl Benzoate (7). Compound 7 was prepared from 2 and benzoyl chloride in the presence of TEA in NMP. Yield 74\%. Recrystallization from EtOH, mp: $145-146^{\circ} \mathrm{C}$. IR ( $\left.\mathrm{KBr}\right) 1651(\mathrm{C}=\mathrm{O}$, amide), $1712\left(\mathrm{C}=\mathrm{O}\right.$, ester), $3332 \mathrm{~cm}^{-1}(\mathrm{NH}) .{ }^{1} \mathrm{H}$ NMR (DMSO- $d_{6}$, ppm): $\delta 10.22(\mathrm{~s}, 1 \mathrm{H}, \mathrm{NH}), 4.48\left(\mathrm{t}, J=7.0 \mathrm{~Hz}, 2 \mathrm{H},-\mathrm{CH}_{2}\right.$ $-\mathrm{O}-\mathrm{C}=\mathrm{O}), 3.02\left(\mathrm{t}, J=7.1 \mathrm{~Hz}, 2 \mathrm{H}, \mathrm{Ph}-\mathrm{CH}_{2}-\right) .{ }^{13} \mathrm{C} \mathrm{NMR}$ (DMSO- $\left.d_{6}, \mathrm{ppm}\right): \delta 165.39(\mathrm{C}=\mathrm{O}$, ester $), 165.19(\mathrm{C}=\mathrm{O}$, amide), $64.87\left(-\mathrm{CH}_{2}-\mathrm{O}-\mathrm{C}=\mathrm{O}\right), 33.39\left(\mathrm{Ph}^{-} \mathrm{CH}_{2}-\right)$. Anal. Calcd for $\mathrm{C}_{22} \mathrm{H}_{19} \mathrm{NO}_{3}$ : C, 76.50; H, 5.54; N, 4.06. Found: C, 76.32; H, 5.40; N, 3.87.

Methyl 3-Phenylcarbamoylbenzoate (8). Compound 8 was prepared from aniline with methyl hydrogen isophthalate in the presence of TEA and DBOP. ${ }^{6}$ Yield 100\%. Mp: $145-146^{\circ} \mathrm{C}$ (from $\mathrm{MeOH} / \mathrm{H}_{2} \mathrm{O}$ ). IR $(\mathrm{KBr}$ ) $1650\left(\mathrm{C}=\mathrm{O}\right.$, amide), $1730(\mathrm{C}=\mathrm{O}$, ester $), 3300 \mathrm{~cm}^{-1}$ (NH). ${ }^{1} \mathrm{H}$ NMR (DMSO- $\left.d_{6}, \mathrm{ppm}\right): \delta 10.47(\mathrm{~s}, 1 \mathrm{H}, \mathrm{NH})$, $3.92\left(\mathrm{~s}, 3 \mathrm{H},-\mathrm{CH}_{3}\right) .{ }^{13} \mathrm{C}$ NMR (DMSO- $\left.d_{6}, \mathrm{ppm}\right): \delta 165.53$ $(\mathrm{C}=\mathrm{O}$, ester $), 164.34(\mathrm{C}=\mathrm{O}$, amide $), 51.89\left(-\mathrm{CH}_{3}\right)$. Anal. Calcd for $\mathrm{C}_{15} \mathrm{H}_{13} \mathrm{NO}_{3}$ : C, 70.58; H, 5.13; N, 5.49. Found: C, $70.39 ; \mathrm{H}, 5.04 ; \mathrm{N}, 5.62$.

\section{Measurements}

The infrared spectra were recorded on a Hitachi I5020-FT-IR spectrophotometer and the NMR spectra on a JEOL EX $270(270 \mathrm{MHz})$ spectrometer. Viscosity measurements were carried out at a concentration of 0.5 $\mathrm{g} \mathrm{dL}^{-1}$ in NMP at $30^{\circ} \mathrm{C}$ by using an Ostwald viscometer. Thermal analyses were performed on a Seiko SSC 5200 TG/DTA 220 thermal analyzer at a heating rate of $10^{\circ} \mathrm{C} \mathrm{min}{ }^{-1}$ and a SSC $5200 \mathrm{DSC} 220$ at a heating rate of $20^{\circ} \mathrm{C} \min ^{-1}$ for differential scanning calorimetry (DSC) under introgen. X-Ray diffraction measurements were carried out by a Rigaku R-AXIS diffractometer (Rigaku Denki Co. Ltd.) operated at $45 \mathrm{kV}$ and $200 \mathrm{~mA} . \mathrm{Cu}-K_{\mathrm{a}}$ $\mathrm{X}$-Ray beams monochromatized with a graphite monochromator were shone onto the specimen through a pinhole collimator of $0.3 \mathrm{~mm}$ in diameter. As an X-Ray detector, the imaging plate (IP) system was utilized. The 
IP was a cylindrical type with a radius of $127.38 \mathrm{~mm}$.

\section{RESULTS AND DISCUSSION}

\section{Competitive Reaction}

Generally sequential polymers are prepared by a multi-step method, and purification of intermediates at each step is important and cumbersome. Therefore, a simple synthetic method would be highly valuable for the preparation of sequential condensation polymers.

For the synthesis of $\mathrm{H}-\mathrm{H}$ or $\mathrm{T}-\mathrm{T}$ ordered polymer by direct polycondensation from a symmetric monomer (YccY) and a nonsymmetric monomer (XabX) (X,Y are leaving groups), two demands must be fulfilled: ${ }^{7}$ One is the sufficient difference (above 100 times) in reactivity between two functional groups $-\mathrm{aX}$ and -bX; the other one is the feed rate, YccY should be added slowly to the solution of XabX. Thus, the following model compound works were performed. The competitive reaction between benzoyl chloride with aniline and phenethyl alcohol in the presence of TEA was carried out in NMP at $0^{\circ} \mathrm{C}$ for $1 \mathrm{~h}$ (eq 1$)$.

The selective acylation of aniline with benzoyl chloride was observed, and the desired product, benzanilide was obtained in quantitative yield, which means that aromatic amino groups show greater reactivity (above 100 times) relative to alcohol groups.

Based on this competitive-reaction result and availability of reagents, we decided to use isophthaloyl chloride (1) and 4-aminophenethyl alcohol (2) as the sym- metric and nonsymmetric monomers, respectively.

\section{Polymer Synthesis}

Authentic Ordered $H-H$ or $T-T$ Poly(amide-ester) $3 a$ by Multi-Step Method. Polymer 3a was prepared by condensation of 1 with [4'-(2-hydroxyethyl)]isophthaldianilide (4), which was prepared from 1 and 2 (eq 2). The polycondensation proceeded smoothly at $0^{\circ} \mathrm{C}$ in $\mathrm{NMP}$, giving polymer $\mathbf{3 a}$ with an inherent viscosity of 0.32 $\mathrm{dL}^{-1}$.

Direct Poly(amide-ester) $3 \boldsymbol{b}$ by One-Step Method. As briefly described above, to obtain $\mathrm{H}-\mathrm{H}$ or $\mathrm{T}-\mathrm{T}$ sequential polymer, YccY should be added slowly to XabX, so that there will never be any unreacted -cY groups. After half of the YccY is added, only XbaccabX will be produced (-aX group in monomer XabX has been arbitrarily chosen to be more reactive). Upon addition of the rest YccY, only $\mathrm{H}-\mathrm{H}$ or $\mathrm{T}-\mathrm{T}$ structure (-accabccb- repeating arrangement) will be formed. ${ }^{8}$ The synthesis of direct poly (amide-ester) $\mathbf{3 b}$ was carried out by slow addition of $\mathbf{1}$ to the solution of 2 at $0^{\circ} \mathrm{C}$. Polymer $\mathbf{3 b}$ produced in quantitative yield with an inherent viscosity of $0.30 \mathrm{dL} \mathrm{g}^{-1}$ (eq 3).

Random Poly(amide-ester) 3c. If nonsymmetric monomer $\mathrm{XabX}$ is mixed all at once with symmetric monomer YccY, only random polymer can be obtained despite of their different reactivities of functional groups $-\mathrm{aX}$ and $-\mathrm{bX} .^{8}$ Random poly(amide-ester) 3c with an inherent viscosity of $0.28 \mathrm{dL} \mathrm{g}^{-1}$ was prepared from 1 and $\mathbf{2}$ by mixing both monomers at once in NMP at room

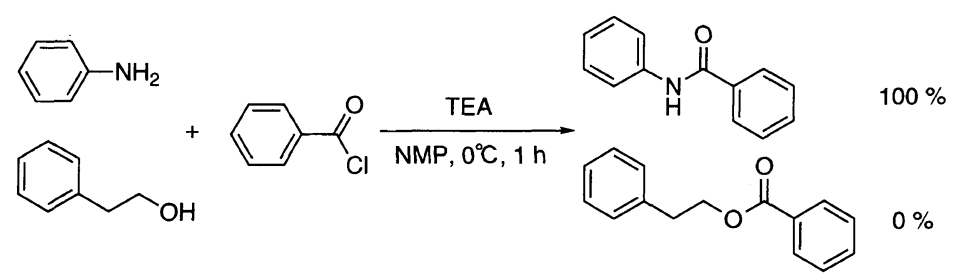

(eq 1)<smiles>Nc1ccc(CCO)cc1</smiles>

(4)

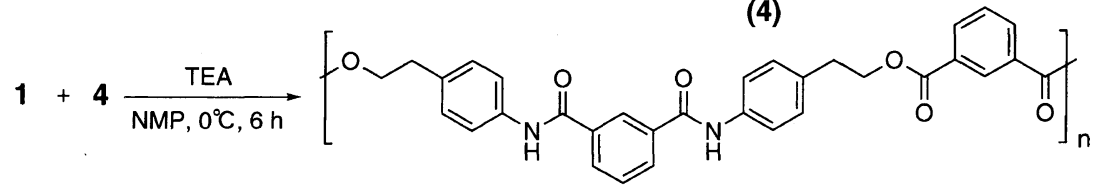

(3a)

(eq 2)

$$
1+2 \frac{\mathrm{TEA}}{\mathrm{NMP}, 0^{\circ} \mathrm{C}, 6 \mathrm{~h}} \text { Polymer 3b }
$$

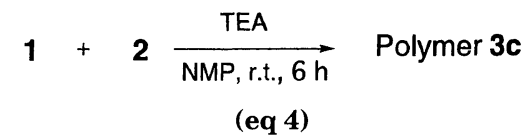

Polym. J., Vol. 33, No. 4, 2001 
temperature (eq 4).

\section{Polymer Characterization}

The IR spectra of all polymers prepared showed characteristic $\mathrm{NH}$, ester and amide carbonyl bands in the range of 3309,1720 , and $1651 \mathrm{~cm}^{-1}$, respectively. Elemental analyses also supported the formation of expected polymers.

The microstructure of polymers was determined by ${ }^{1} \mathrm{H}$ and ${ }^{13} \mathrm{C}$ NMR, taken in DMSO- $d_{6}$ using TMS as internal reference. Figure 1 showed the ${ }^{1} \mathrm{H}$ NMR spectrum of polymer 3b. All peaks were assigned, as shown in the inset of Figure 1. These findings clearly indicated the formation of expected polymer $3 \mathbf{b}$. However, all ${ }^{1} \mathrm{H}$ NMR spectra of polymers $\mathbf{3 a}, \mathbf{3 b}$, and $\mathbf{3 c}$ were identical in spite of the different regularity. It can be assumed that the differences in chemical shift of meta-disubstituted benzene ring with amide or ester bonds in polymer $\mathbf{3 a}$ and 3c were too small to be detected. ${ }^{1} \mathrm{H}$ NMR chemical

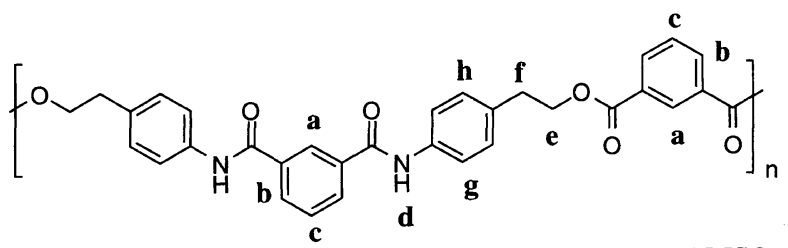

Direct poly(amide-ester) 3b

DMSO- $_{6}$

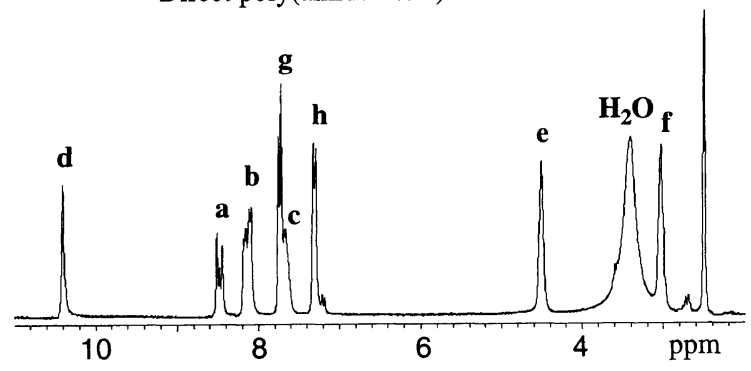

Figure 1. ${ }^{1} \mathrm{H}$ NMR spectrum of polymer $3 \mathbf{b}$ in DMSO- $d_{6}$.

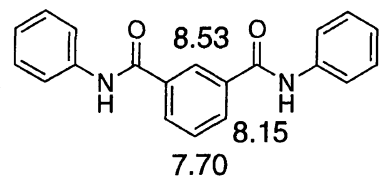

model compound 5

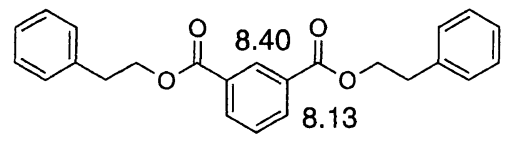

7.64

model compound 6

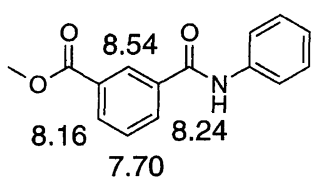

model compound 8

(eq 5) shifts of model compounds supported this observation (eq 5).

The expanded ${ }^{13} \mathrm{C}$ NMR spectra in aromatic region of polymer 3 were presented in Figure 2 (detail see Scheme 1), the assignments were also carried out on bases of the ${ }^{13} \mathrm{C}$ NMR chemical shifts of model compounds (eq 6).

The spectrum of $\mathbf{3 b}$ was identical to that of polymer $\mathbf{3 a}$, and very different from that of polymer 3c containing peaks derived from $\mathrm{H}-\mathrm{T}$ segment. The ratio $(s)$ of $\mathrm{H}-$ $\mathrm{H}$ or $\mathrm{T}-\mathrm{T}$ and $\mathrm{H}-\mathrm{T}$ units was estimated to be 0.49 based on the following equation using each peak area.

$$
s=\text { peak } 7 /\left(\text { peak } 1+\text { peak } 7+\text { peak } 1^{\prime \prime}\right)
$$

This value agreed well with that of the random polymer. These findings indicated that direct polycondensation of 1 and 2 can produce desired $\mathrm{H}-\mathrm{H}$ or $\mathrm{T}-\mathrm{T}$ ordered poly (amide-ester).

No great difference was observed in the spectra of carbonyl region for polymers $\mathbf{3}$. Four peaks of carbon nuclei for polymer 3c should be observed in carbonyl region, only two peaks appeared just same with that of $\mathrm{H}-\mathrm{H}$ or $\mathrm{T}-\mathrm{T}$ ordered polymer $\mathbf{3 b}$. This may be explained that the two signals of carbonyl were too close $(164.70 \mathrm{ppm}$ for amide and, $164.58 \mathrm{ppm}$ for ester) to detect the difference.

The polymers obtained were white powders and soluble in sulfuric acid, dipolar aprotic solvents, such as NMP, DMF, $m$-cresol, and DMSO, and completely insol-

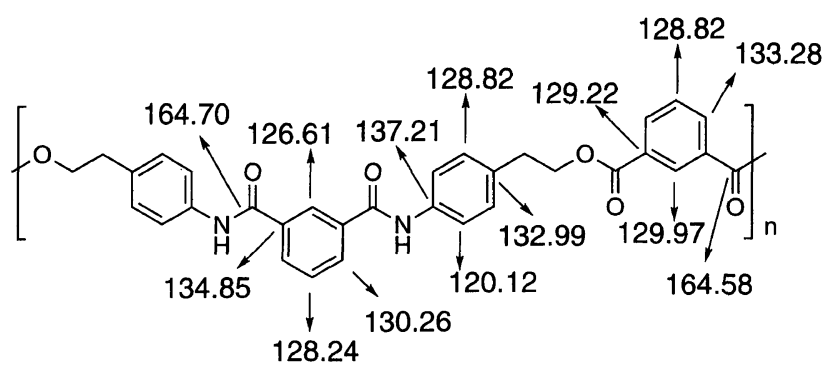

H-H or T-T ordered polymer 3a

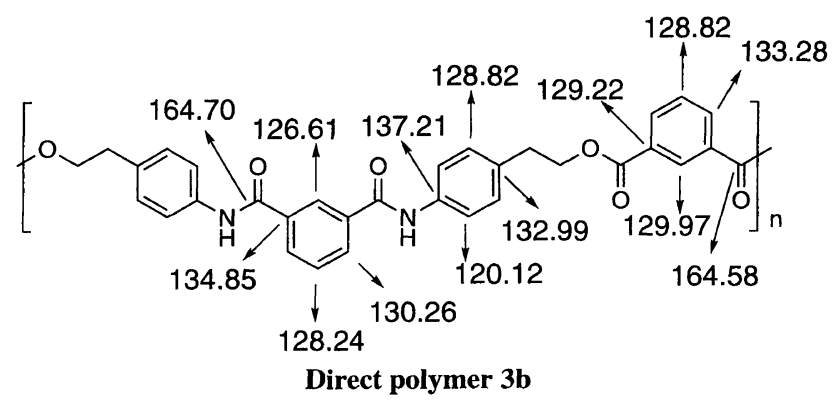

H-T segment in random polymer $3 \mathrm{c}$ Scheme 1. 


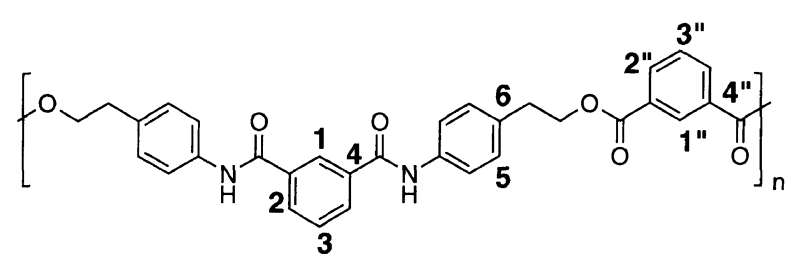
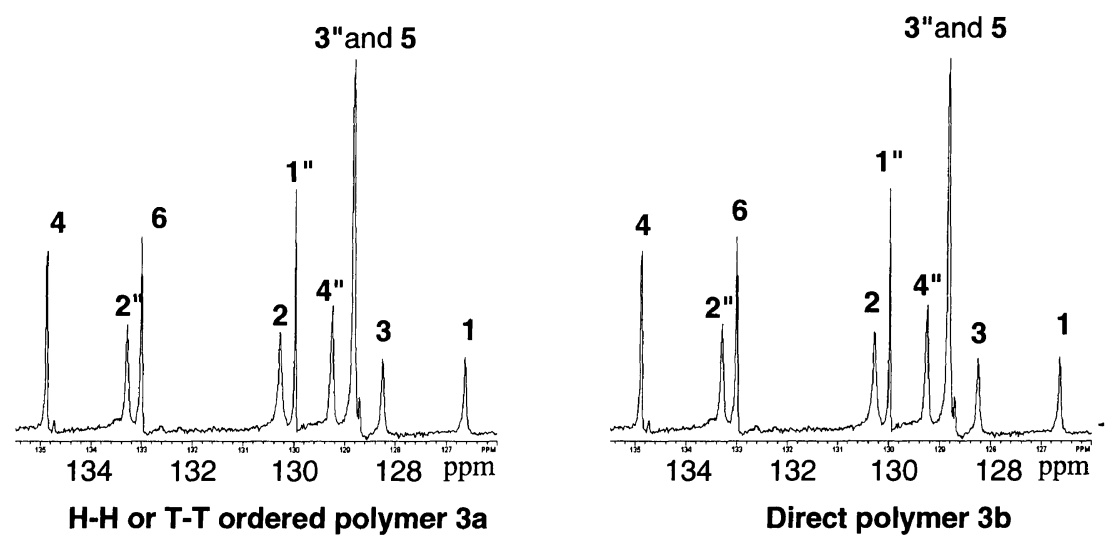<smiles>CC(C)OCCc1ccc(NC(=O)c2cccc(C(=O)Nc3ccc(CCOC(=O)c4ccccc4)cc3)c2)cc1</smiles>

H-H or T-T segment

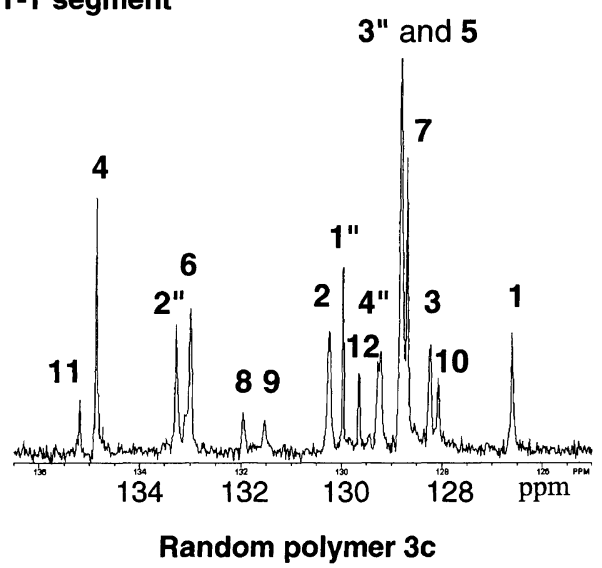<smiles>CCCc1ccc(NC(=O)c2ccccc2C(=O)OCC)cc1</smiles>

H-T segment

Figure 2. Expanded ${ }^{13} \mathrm{C}$ NMR spectra of polymer 3a, 3b, and $\mathbf{3} \mathbf{c}$ in DMSO- $d_{6}$.

uble in $\mathrm{MeOH}, \mathrm{THF}$, and $\mathrm{H}_{2} \mathrm{O}$. The solubility behavior of polymers $\mathbf{3 b}$ and $\mathbf{3 c}$ was almost the same in spite of their different regularities.

\section{Thermal Properties of Polymers}

The thermal properties of polymers $\mathbf{3 b}$ and $\mathbf{3 c}$ were examined by thermogravimetry (TG) and differencential scanning calorimetry (DSC). The polymers showed rapid weight loss started at about $350^{\circ} \mathrm{C}$ both in nitrogen and air. Difference in thermal degradation behavior between $\mathbf{3 b}$ and $\mathbf{3 c}$ was not detected.

DSC traces of the first-heating process for polymers $\mathbf{3 b}$ and 3c were illustrated in Figure 3 . The DSC trace of polymer $3 \mathbf{b}$ showed a base-line shift around $150^{\circ} \mathrm{C}$ corre- sponding to a glass transition $\left(T_{\mathrm{g}}\right)$, an exothermic and an endothermic peaks were observed at $217^{\circ} \mathrm{C}$ and $262^{\circ} \mathrm{C}$, respectively. The exothermic peak resulted from the cold crystallization which was occurred by rearrangement of molecular chains above $T_{\mathrm{g}}$. On the other hand, the DSC trace of polymer 3c exhibited only a glass transition profile; no endothermic peak was observed. Thus, polymer 3c was considered to be amorphous due to the random sequence which cannot form regular chain conformation.

As shown in Figure 4, the second-heating DSC traces of polymers $\mathbf{3 b}$ and $\mathbf{3 c}$ were similar to their first traces, though the exothermic peak of polymer $\mathbf{3 b}$ became smaller. The decrease in the exothermic peak suggested that the crystallization occurred during the cooling proc- 
<smiles>Cc1c(C(=O)O)cc(C(=O)O)c(C(=O)O)c1C(=O)Nc1ccccc1</smiles><smiles>Cc1cc(C(=O)OCCc2ccccc2)c(C(=O)O[18O])c(C)c1C(=O)OCCc1ccccc1</smiles>

model compound 6<smiles>O=C(Nc1cc(CCOC(=O)c2ccccc2)c([18OH])cc1CC[18O])c1ccccc1</smiles>

model compound 7

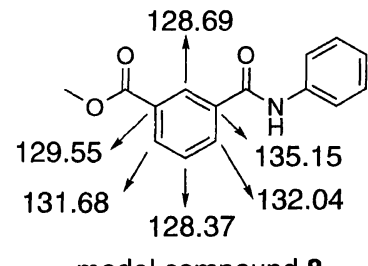

model compound 8

(eq 6)

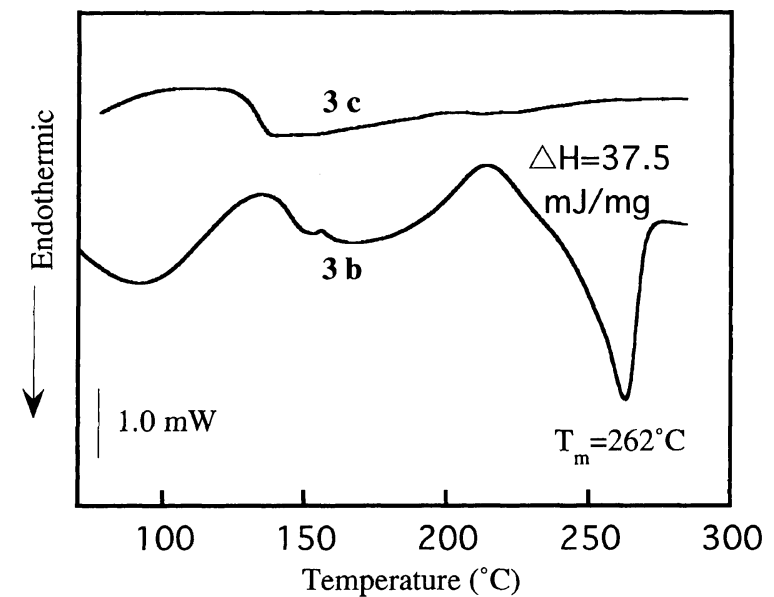

Figure 3. DSC traces of the first-heating process for polymers $\mathbf{3 b}$ and $\mathbf{3 c}$.

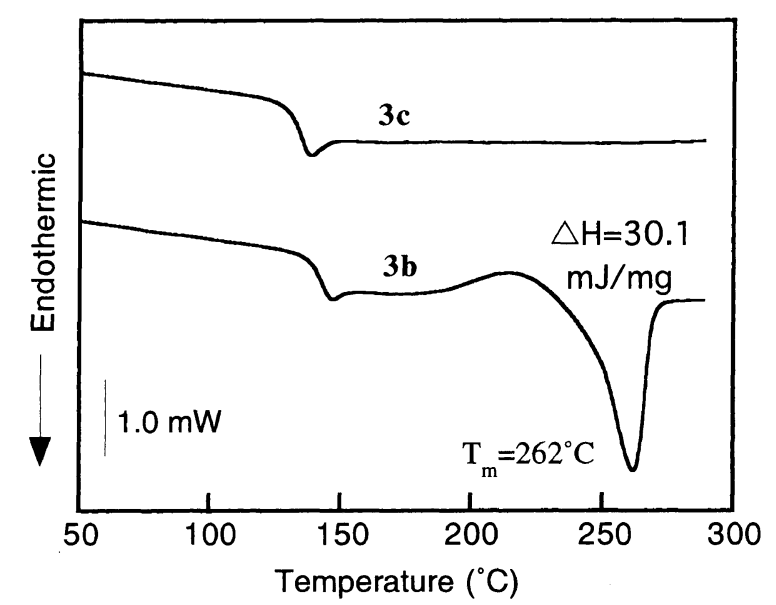

Figure 4. DSC traces of the second-heating process for polymers $3 \mathbf{b}$ and $3 \mathbf{c}$.<smiles>CC(C)(C)OCCc1ccc(NC(=O)c2cccc(C(=O)Nc3ccc(CCNC(=O)c4cccc(C(=O)Nc5ccc(CCNC(=O)c6cccc(C(C)(C)C)c6)cc5)c4)cc3)c2)cc1</smiles>

H-H or T-T ordered poly(amide-ester) $3 b \mathrm{~T}_{\mathrm{m}}: 262^{\circ} \mathrm{C}$

Scheme 2.

ess from the melt. The $T_{\mathrm{g}} \mathrm{s}$ of $\mathbf{3 b}$ and $3 \mathbf{c}$ were 142 and $135^{\circ} \mathrm{C}$, respectively, indicating the difference of structural regularity.

The thermal behavior of polymer $\mathbf{3 b}$ was different from that of the $\mathrm{H}-\mathrm{H}$ or $\mathrm{T}-\mathrm{T}$ ordered poly(amide-ester) (9) prepared from isophthaloyl chloride (1) and 4-(2aminoethyl)phenol (Scheme 2). As described in Introduction, no endothermic peak was observed in the secondheating DSC trace for polymer $\mathbf{9}$, though its first-heating trace of as-made sample showed endothermic peak. Aliphatic ester bonds in polymer $\mathbf{3 b}$ are more flexible than aromatic ester ones, so it is possible for polymer $\mathbf{3 b}$ to remove again and form regular packing in cooling.

The WAXD intensity curve of polymer $\mathbf{3 b}$ represented several reflections indicating semicrystalline nature, as shown in Figure 5. Its degree of crystallinity was about $40 \%$ estimated using the X-Ray method. This finding supported that the endothermic peak in the DSC curve 


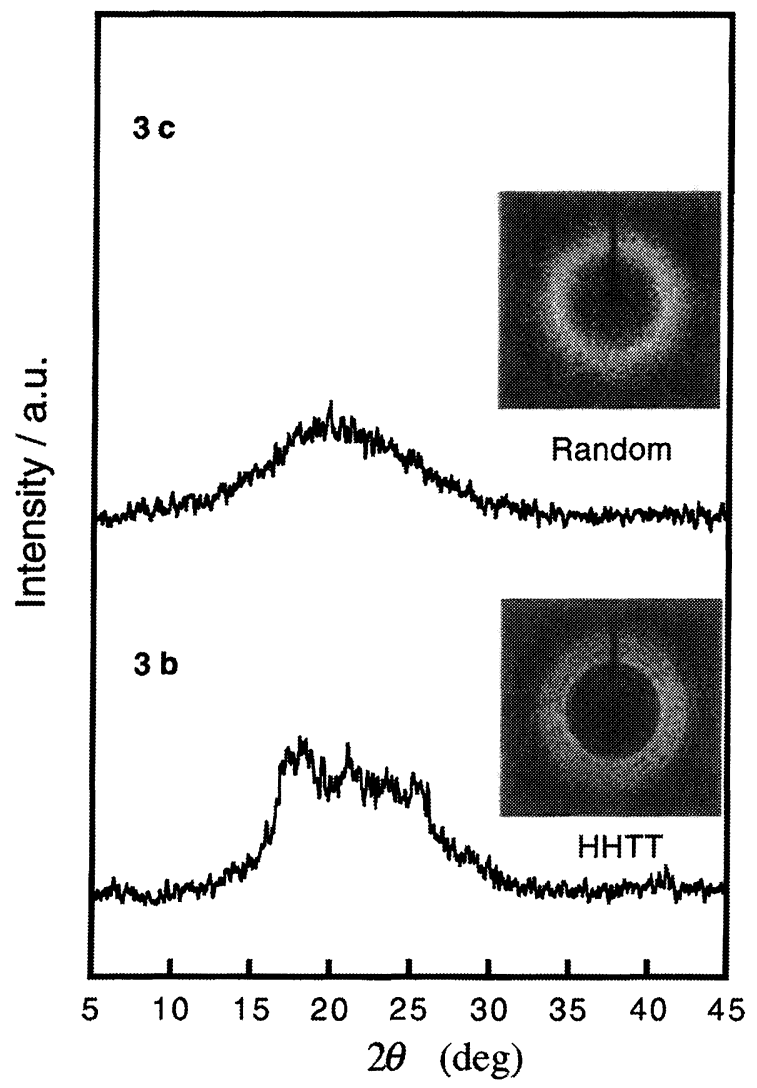

Figure 5. WAXD intensity traces and photographs for as-made polymers $\mathbf{3 b}$ and $\mathbf{3 c}$

of polymer $\mathbf{3 b}$ corresponded to $T_{\mathrm{m}}$. Polymer $3 \mathbf{c}$, on the other hand, showed an amorphous profile due to its random chain sequence.

Figure 6 demonstrated the WAXD intensity traces and photographs for polymer $\mathbf{3 b}$ after annealing treatment at 200 and $240^{\circ} \mathrm{C}$ close to $T_{\mathrm{m}}$ for $2 \mathrm{~h}$ respectively. The reflections became sharp and the intensity of the reflections remarkably increased. The degrees of crystallinity of polymer $3 \mathbf{b}$ were increased to $54 \%$ and $63 \%$, respectively. These findings suggest that the partical melt and recrystallization occurred during annealing at the high temperature close to $T_{\mathrm{m}}$.

\section{CONCLUSION}

In summary, we have demonstrated the synthesis of $\mathrm{H}-\mathrm{H}$ or $\mathrm{T}-\mathrm{T}$ ordered poly(amide-ester) $\mathbf{3 b}$ can be achieved by direct polycondensation of symmetric monomer 1 with nonsymmetric monomer 2 . The microstructure of polymer $\mathbf{3 b}$ was superimposed with the ${ }^{1} \mathrm{H}$ and ${ }^{13} \mathrm{C}$ NMR spectra of authentic $\mathrm{H}-\mathrm{H}$ or $\mathrm{T}-\mathrm{T}$ ordered polymer 3a obtained by multi-step route. The constitutional isomerism of polymers influenced their thermal properties and crystallinity.

Acknowledgments. This work was financially supported by New Energy and Industrial Technology Developement Organization (NEDO) for the project on Technology for Novel High-Functional Materials and Agency of Industrial Science and Technology (AIST). And we

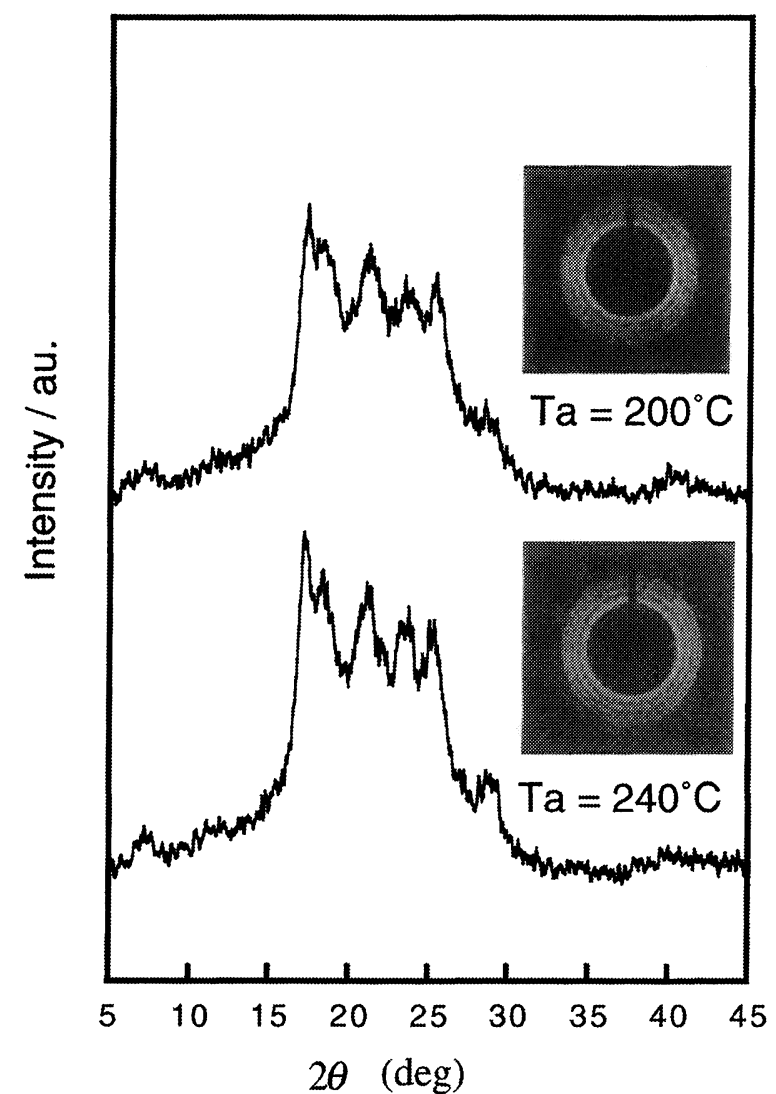

Figure 6. WAXD intensity traces and photographs for polymer $\mathbf{3 b}$ after annealing treatment at 200 and $240^{\circ} \mathrm{C}$ for $2 \mathrm{~h}$ respectively.

also thank the Japan Chemical Innovation Institute (JCII) for financial support. We are indebted to $\mathrm{Mr}$. Sadao Kato for his assistance and Mr. Takeyoshi Takehashi for performing the elementary analyses.

\section{REFERENCES}

1. a) M. Ueda, M. Kakuta, T. Morosumi, and R. Sato, Polym J., 23, 167 (1991). b) M. Ueda, T. Morosumi, and M. Kakuta, Polym. J., 23, 1151 (1991). c) M. Ueda, T. Morosumi, M. Kakuta, and J. Sugiyama, Macromolecules, 25, 6580 (1992). d) M. Ueda and H. Sugiyama, Macromolecules, 27, 240 (1994). e) M. Ueda and T. Okada, Macromolecules, 27, 3449 (1994). f) M. Ueda, A. Takabayashi, and H. Seino, Macromolecules, 30, 363 (1997). g) O. Haba, H. Seino, K. Iguchi, K. Aoki, and M. Ueda, J. Polym. Sci., Part A: Polym. Chem., 36, 2309 (1998).

2. a) L. Li, H. Seino, K. Yonetake, and M. Ueda, Macromolecules, 32, 3851 (1999). b) L. Li, T. Hayakawa, K. Yonetake, and M. Ueda, Macromol. Chem. Phys., 201, 1667 (2000).

3. L. Li, K. Yonetake, and M. Ueda, Macromol. Chem. Phys., in press.

4. M. Ueda, M. Kameyama, and K. Hashimoto, Macromolecules, 21, 19 (1988).

5. R. Koch, Ber. Dtsch. Chem. Ges., 46, 1019 (1913).

6. a) S. Morijima, Master Thesis, Yamagata Univ., 1996, p 35. b) A. W. Smith, Ber. Dtsch. Chem. Ges., 24, 4047 (1891).

7. a) P. Pino, G. P. Lorenzi, U. W. Suter, P. G. Casartelli, A. Steinmann, F. J. Bonner, and J. A. Quiroga, Macromolecules, 11, 624 (1978). b) U. W. Suter and P. Pino, Macromolecules, 17, 2248 (1984)

8. S. G. Allen, "Comprehensive Polymer Science," Pergamon, New York, N.Y., 1989, vol. 5, p 97. 